\title{
The effects of abomasal infusions of casein or soya-bean-protein isolate on the milk production of dairy cows in mid-lactation
}

\author{
BY JAI-JUN CHOUNG AND DAVID G. CHAMBERLAIN* \\ Hannah Research Institute, Ayr KA6 $5 \mathrm{HL}$
}

(Received 8 May 1991 - Accepted 21 February 1992)

\begin{abstract}
The effects of abomasal infusion of casein or soya-bean-protein isolate (SPI) on milk production were investigated in four Friesian cows in mid-lactation receiving a basal diet of grass silage and barley which supplied energy and protein considerably in excess of requirements for milk production by conventional rationing standards. Three levels of infusion were used for each protein source, the corresponding doses being isonitrogenous for each of the proteins: 100,220 and $330 \mathrm{~g} / \mathrm{d}$ for casein and 115,230 and $345 \mathrm{~g} / \mathrm{d}$ for SPI. Casein produced much greater effects on the yield of milk and milk constituents than did SPI. On the highest dose of casein, milk yield was increased by $3.5 \mathrm{~kg} / \mathrm{d}$, fat output by $15 \%$ and protein output by $36 \%$; corresponding values for the highest dose of SPI were $1.6 \mathrm{~kg} / \mathrm{d}, 12 \%$ and $13 \%$ respectively. Increases in the yield of milk-protein were linear for casein but for SPI there was no increase beyond the first level of infusion. It was calculated that casein infusion had a marked effect on the utilization of energy : the increases in milk production could be explained either by a channelling of an extra $12 \mathrm{MJ}$ metabolizable energy (ME)/d away from body tissue synthesis and into milk synthesis or by an increase in the efficiency of utilization of ME for lactation from 0.50 on the basal diet to 0.58 ; the measurements made did not allow the two mechanisms to be clearly differentiated.
\end{abstract}

Abomasal protein infusions: Casein: Soya-bean-protein isolate: Milk production: Dairy cow

There are a number of reports of increased milk production of dairy cows in response to the infusion of casein into the abomasum (see Clark, 1975; Ørskov et al. 1977; Rulquin, 1982; König et al. 1984; Whitelaw et al. 1986). Responses were greatest when energy intake in early lactation was restricted to ensure some dependence on body energy stores (Ørskov et al. 1977; Whitelaw et al. 1986).

Two questions are raised: (1) If casein infusion can stimulate mobilization of body fat when energy intake is restricted in early lactation, can it influence the pattern of energy use in cows in mid-lactation consuming energy and protein in excess of their requirements for milk production? (2) how do the responses elicited by casein relate to those obtained with a protein more representative of those used in practice?

The experiment reported here compared the effects of abomasal infusions of casein and of soya-bean protein. Both proteins were infused at three dose levels in cows in midlactation receiving a diet containing a fixed amount of barley and high-quality grass silage offered ad lib.

\section{MATERIALS AND METHODS}

Animals and management

Four Friesian cows in their third or fourth lactation were used. The cows were approximately 20 weeks into their lactations at the start of the experiment and ranged from 500 to $560 \mathrm{~kg}$ live weight (mean $526 \mathrm{~kg}$ ). Each animal was fitted with an infusion catheter

* For reprints. 
Table 1. The chemical composition ( $\mathrm{g} / \mathrm{kg}$ dry matter $(D M)$ unless stated otherwise) of the silage and barley

\begin{tabular}{|c|c|c|}
\hline & Silage & Barley \\
\hline $\mathrm{DM}(\mathrm{g} / \mathrm{kg})$ & $213^{*}$ & 803 \\
\hline Organic matter & 917 & 977 \\
\hline Total nitrogen & $24 \cdot 6$ & $17 \cdot 7$ \\
\hline Ammonia-N (g/kg N) & 148 & ND \\
\hline NDF & 523 & 190 \\
\hline ADF & 331 & 61 \\
\hline M-ADF & 348 & ND \\
\hline Starch & ND & 630 \\
\hline $\mathrm{pH}$ & 3.73 & ND \\
\hline Water-soluble carbohydrate & 7 & ND \\
\hline Lactic acid & 84 & ND \\
\hline Acetic acid & 17 & ND \\
\hline Butyric acid & 0 & ND \\
\hline Ethanol & 32 & ND \\
\hline
\end{tabular}

ND, not determined; NDF, neutral-detergent fibre; ADF, acid-detergent fibre; M-ADF, modified aciddetergent fibre.

* Determined by toluene distillation (Dewar \& McDonald, 1961).

into the abomasum, inserted 5-6 weeks after calving, using a procedure similar to that described by MacLeod et al. (1982) except that general anaesthesia was used. The animals were housed individually in metabolism stalls and milked each day at 06.00 and 16.00 hours.

\section{Design and treatments}

All animals received the basal diet for $14 \mathrm{~d}$ before the start of the experiment. The four cows were used in two consecutive $4 \times 4$ Latin squares separated by 1 week. In the first Latin square the treatments were: (1) basal diet, (2) basal diet plus $110 \mathrm{~g}$ casein/d infused into the abomasum, (3) basal diet plus $220 \mathrm{~g}$ casein/d infused into the abomasum and (4) basal diet plus $330 \mathrm{~g}$ casein/d infused into the abomasum. In the second Latin square the treatments were as in the first except that the three protein infusion treatments were 115,230 and $345 \mathrm{~g}$ soya-bean-protein isolate (SPI)/d. The casein was obtained from BDH Ltd, Poole, Dorset and the SPI from The British Arkady Co. Ltd, Manchester. The doses of SPI were designed to be isonitrogenous with the corresponding doses of casein. All infusions were dissolved in water and infused continuously in a volume of $6 \mathrm{l} / \mathrm{d}$ using a peristaltic pump (Watson Marlow, Falmouth, Cornwall) during a $23 \mathrm{~h}$ period each day. Each experimental period was $10 \mathrm{~d}$ long.

During the final period of the second Latin square, one animal on the basal treatment developed mastitis and was withdrawn from the experiment. For statistical analysis, a missing plot was generated by Genstat.

\section{Diet and feeding}

The basal diet consisted of grass silage $a d \mathrm{lib}$. and $5 \mathrm{~kg}$ barley/d (fresh weight). Food was given in two meals/d at 06.00 and 16.00 hours, the silage being given in amounts sufficient to ensure a refusal of about $15 \%$ of that offered and food intake was measured daily.

The chemical composition of the silage and barley is given in Table 1 . The silage was made from perennial ryegrass (Lolium perenne) cut at an early stage of growth and ensiled 
Table 2. The amino acid composition ( $\mathrm{g} / \mathrm{kg}$ crude protein) of the infused proteins

\begin{tabular}{lcc}
\hline \hline & Casein & Soya-bean-protein isolate \\
\hline Total nitrogen (g/kg DM) & $145 \cdot 3$ & 141.8 \\
Essential amino acids & 28 & 23 \\
$\quad$ Histidine & 48 & 41 \\
Threonine & 40 & 72 \\
Arginine & 33 & 15 \\
Methionine & 70 & 47 \\
Valine & 59 & 53 \\
Phenylalanine & 55 & 45 \\
Isoleucine & 102 & 78 \\
Leucine & 82 & 48 \\
Lysine & & \\
Non-essential amino acids & 77 & 112 \\
Aspartic acid & 153 & 115 \\
Glutamic acid & 70 & 56 \\
Serine & 21 & 41 \\
Glycine & 34 & 42 \\
Alanine & 62 & 40 \\
Tyrosine & 934 & 828 \\
Total amino acids & & \\
\hline
\end{tabular}

DM, dry matter.

with the addition of 31 Add-Safe (550 g ammonium tri-hydrogen tetraformate, $150 \mathrm{~g}$ ammonium tri-hydrogen tetrapropionate/1; BP Chemicals Ltd)/tonne fresh grass. The silage was well preserved with a low $\mathrm{pH}$ and the absence of butyric acid. The crude protein $(\mathrm{N} \times 6.25)$ concentration in the total diet was approximately $142 \mathrm{~g} / \mathrm{kg}$ dry matter (DM).

The amino acid composition of the infused protein sources is shown in Table 2 . The total amino acid concentration was higher for casein than for SPI. SPI was substantially lower in methionine, valine, leucine and lysine and higher in arginine than the corresponding values in casein. The amino acid composition of SPI was similar to that of samples of soya-bean meal analysed in this laboratory.

\section{Milk recording and analysis}

Milk yield was recorded daily and the composition of milk was determined on a bulked sample of the last four consecutive milkings in each experimental period. For statistical analysis, the milk yield for each period was taken as the mean of the last $7 \mathrm{~d}$ of the period.

\section{Blood sampling}

Blood samples were obtained by venepuncture from the tail at 10.00 and 14.00 hours on the last $2 \mathrm{~d}$ of each period. Samples were taken into heparinized tubes and centrifuged immediately to separate plasma which was stored at $-20^{\circ}$. Samples from each cow were bulked before analysis for glucose, urea, $\beta$-hydroxybutyrate, non-esterified fatty acids (NEFA) and amino acids.

\section{Analytical methods}

DM of feed samples was determined by the toluene method of Dewar \& McDonald (1961) for silage and by drying at $100^{\circ}$ for barley. Organic matter $(\mathrm{OM})$ was determined by ashing at $550^{\circ}$. Total $\mathrm{N}$ was determined by a Kjeldahl technique. Ammonia in silage was liberated by $\mathrm{NaOH}$, removed by steam distillation and determined titrimetrically. 
Other analyses were for short-chain fatty acids (Cottyn \& Boucque, 1968), water-soluble carbohydrate (Somogyi, 1945), starch (MacRae \& Armstrong, 1968), neutral-detergent fibre (NDF) and acid-detergent fibre (ADF; Goering \& Van Soest, 1970), modified ADF (Ministry of Agriculture, Fisheries and Food, 1981), lactic acid (Elsden \& Gibson, 1954) and ethanol (Huida, 1982).

Milk samples were analysed for total solids gravimetrically, for fat by the Gerber method, for total protein $(\mathrm{N} \times 6.38)$ by a Kjeldahl procedure, for non-protein- $\mathrm{N}(\mathrm{NPN})$ by the method of Waite et al. (1956), for lactose polarimetrically and for fatty acids by gas-liquid chromatography (Thomas \& Kelly, 1976).

Blood was analysed using commercial test kits for the following constituents: glucose (Boehringer Ltd, Lewes, East Sussex), urea (Boehringer Ltd), NEFA (Wako Chemicals, Neuss, Germany) and $\beta$-hydroxybutyrate (Sigma Chemical Co., Poole, Dorset).

Amino acids in plasma and infusates were determined by the method of Umagat et al. (1982) using HPLC with OPA/MCE precolumn derivatization. The HPLC system consisted of a Spectra-Physics Model SP8700 solvent delivery system (Anachem Ltd, Luton, Beds.) coupled to a Gilson Model 121 filter fluorimeter (Anachem Ltd). Separations were carried out on a $250 \times 4.6 \mathrm{~mm}$ i.d. Apex II column prepacked with $5 \mu \mathrm{m}$ octadecyl particles (Jones Chromatography, Hengoed, Mid Glamorgan). Before analysis casein and SPI were hydrolysed with $6 \mathrm{M}-\mathrm{HCl}$ containing mercaptoethanol to protect methionine from oxidation (Keutmann \& Potts, 1969) and plasma samples were deproteinized with $80 \mathrm{~g} 5$ sulphosalicylic acid $/ 1$.

\section{Statistical analysis}

There were four cows and two protein sources each at three non-zero levels. The experiment was designed as two $4 \times 4$ Latin squares with a $7 \mathrm{~d}$ interval between. Each square contained only one protein source, at all four levels, the zero level being regarded as the control. The same four cows were used for the two squares. This design means that if there is a 'square' or period effect it will be confounded with the source effect. However, no significant period effect was found when analysing each square separately, and so the two squares were analysed together to take advantage of the fact that the same cows were used for each. The period effect was ignored and the model fitted (Payne et al. 1987) included terms for cows, zero values, positive levels of protein, type of protein and differences between positive levels for protein.

\section{RESULTS}

Food intake

Differences in food intake (Table 3) reflected differences in silage intake, the barley intake being fixed at $4 \mathrm{~kg} \mathrm{DM} / \mathrm{d}$. None of the differences in silage intake was significant $(P>$ $0 \cdot 05$ ), but the difference in intake between the highest level of casein infusion and the basal treatment approached significance $(0 \cdot 10>P>0.05)$.

\section{Milk yield and composition}

All animals reached their maximum level of response in milk yield within $3 \mathrm{~d}$ of the start of infusion treatments. There was a progressive increase in milk yield with each level of infusion for both protein sources but, for each level of infusion, increases were greater (at least $P<0.05$ ) for casein than for corresponding levels of SPI (Table 3 ). The concentration of fat in the milk was high throughout and showed no significant differences $(P>0.05)$ between treatments. In general, protein infusion tended to increase the concentration of protein in milk compared with the basal treatment but this was significant $(P<0.05)$ only for the highest level of casein. Protein infusion tended to decrease lactose concentration, 


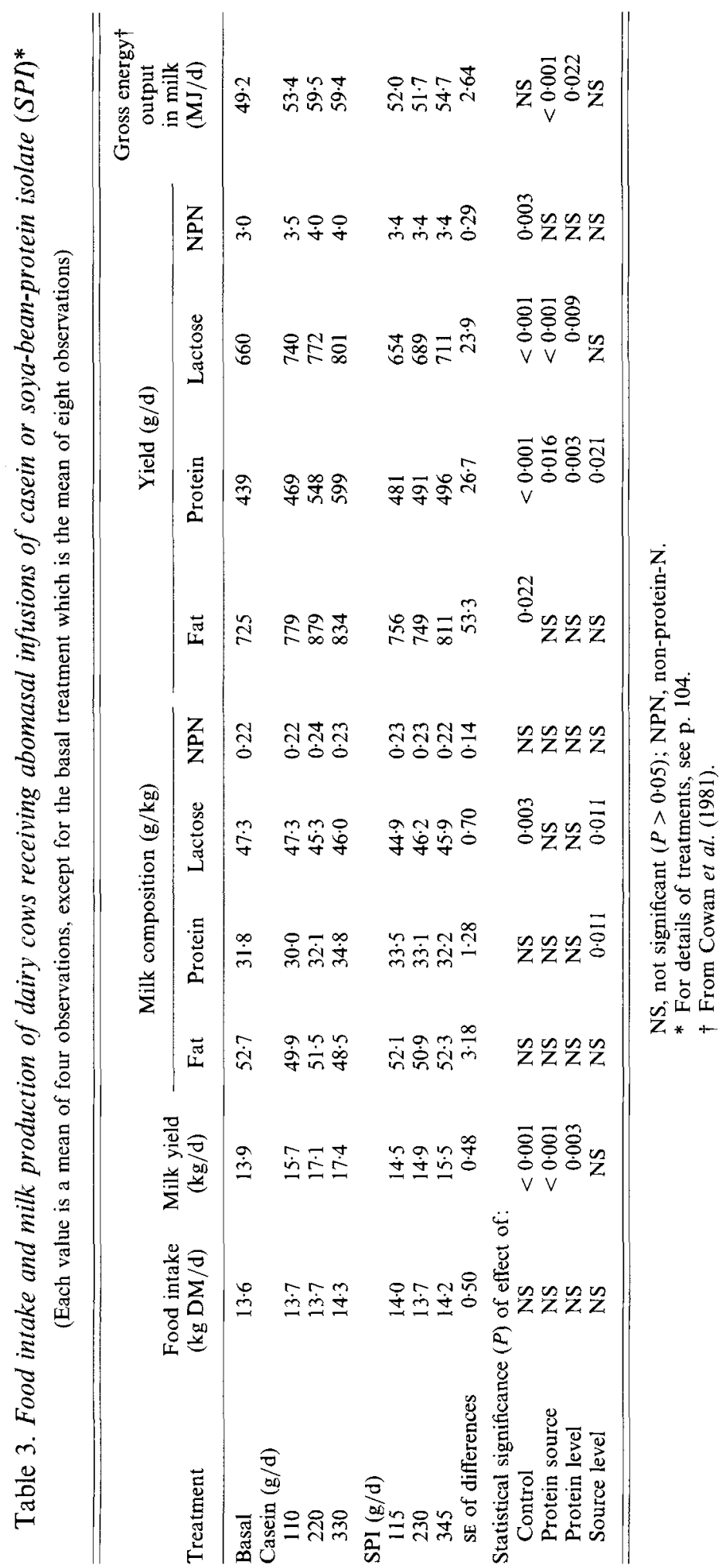


this effect being significant $(P<0.05)$ for the lowest and the highest levels of SPI. There were no effects $(P>0.05)$ of protein infusion on NPN concentration in milk. The yield of milk protein increased progressively with the level of casein infusion but with SPI the differences between infusion levels in the yield of milk protein were small and not significant $(P>0.05)$; only for the highest level of SPI was the increase in protein yield over the basal treatment significant $(P<0 \cdot 05)$. Although the output of fat in milk tended to be increased by protein infusion, the effect was significant $(P<0.05)$ only for the two highest levels of casein. The yield of lactose was progressively increased with each protein source but the effect was greater with casein.

The fatty acid composition of the milk fat (Table 4) showed a number of statistically significant $(P<0.05)$ differences between treatments but, overall, the differences were small. The proportion of total $\left(\mathrm{C}_{4}-\mathrm{C}_{16}\right)$ acids was greater for casein than for SPI at all levels of infusion. SPI infusion tended to increase the proportion of $\mathrm{C}_{18: 1}$ compared with the basal and the casein treatments. Both protein sources produced similar increases in the yield of total $\mathrm{C}_{18}$ fatty acids in milk fat but casein produced markedly greater increases in the output of fatty acids synthesized de novo in the mammary gland.

\section{Blood plasma analyses}

The effects of protein infusions on the plasma concentrations of some metabolites are shown in Table 5. There were small differences in glucose concentrations but only for the lowest level of SPI infusion was the value significantly greater $(P<0.05)$ than that for the basal treatment. Casein infusion tended to increase and SPI tended to decrease concentrations of $\beta$-hydroxybutyrate relative to the basal treatment, with the result that, at each level of infusion, the values for casein were significantly higher $(P<0.05)$ than for the corresponding level of SPI. A similar trend was seen in the concentrations of NEFA; at all levels of infusion, casein increased $(P<0.05)$ and SPI decreased $(P<0.05)$ NEFA concentrations compared with the zero-infusion treatment. Urea levels were not affected by SPI infusions, the only significant $(P<0.05)$ effect was an increase with the $220 \mathrm{~g}$ casein $/ \mathrm{d}$ level.

The concentrations of amino acids in blood plasma are given in Table 6. For both protein sources, the concentration of total amino acids increased progressively as the level of infusion was increased but the increases were not statistically significant $(P>0.05)$. For some of the essential amino acids the changes in concentration with protein infusion were significant $(P<0.05)$ but for the non-essential amino acids there were no significant effects $(P>0.05)$. In general, infusion of casein and SPI increased the concentrations of methionine, lysine, histidine and the branched-chain amino acids (valine, leucine, isoleucine) relative to the basal control $(P<0 \cdot 05)$.

\section{DISCUSSION}

It was intended that the cows be in substantial, positive energy balance on the basal treatment. To this end, the animals selected were in mid-to-late lactation and were offered high-quality grass silage $a d$ lib. and a fixed level of barley as a supplement. Calorimetric measurements were not made but an estimate of the energy status of the cows can be deduced. The metabolizable energy (ME) value of the silage can be estimated from its concentration of modified ADF (Givens, 1986) to be $10.7 \mathrm{MJ} / \mathrm{kg} \mathrm{DM}$. Taking a value of $13 \mathrm{MJ} \mathrm{ME} / \mathrm{kg} \mathrm{DM}$ for barley, the intake of ME on the basal diet was $155 \mathrm{MJ} / \mathrm{d}$. The ME requirement for maintenance (Agricultural Research Council 1980) was $50 \mathrm{MJ} / \mathrm{d}$ and the efficiency of utilization of ME for lactation $\left(k_{l}\right)$ was 0.63 (Agricultural Research Council, 1980 ). Using these factors, the ME required to meet the cost of maintenance and the 


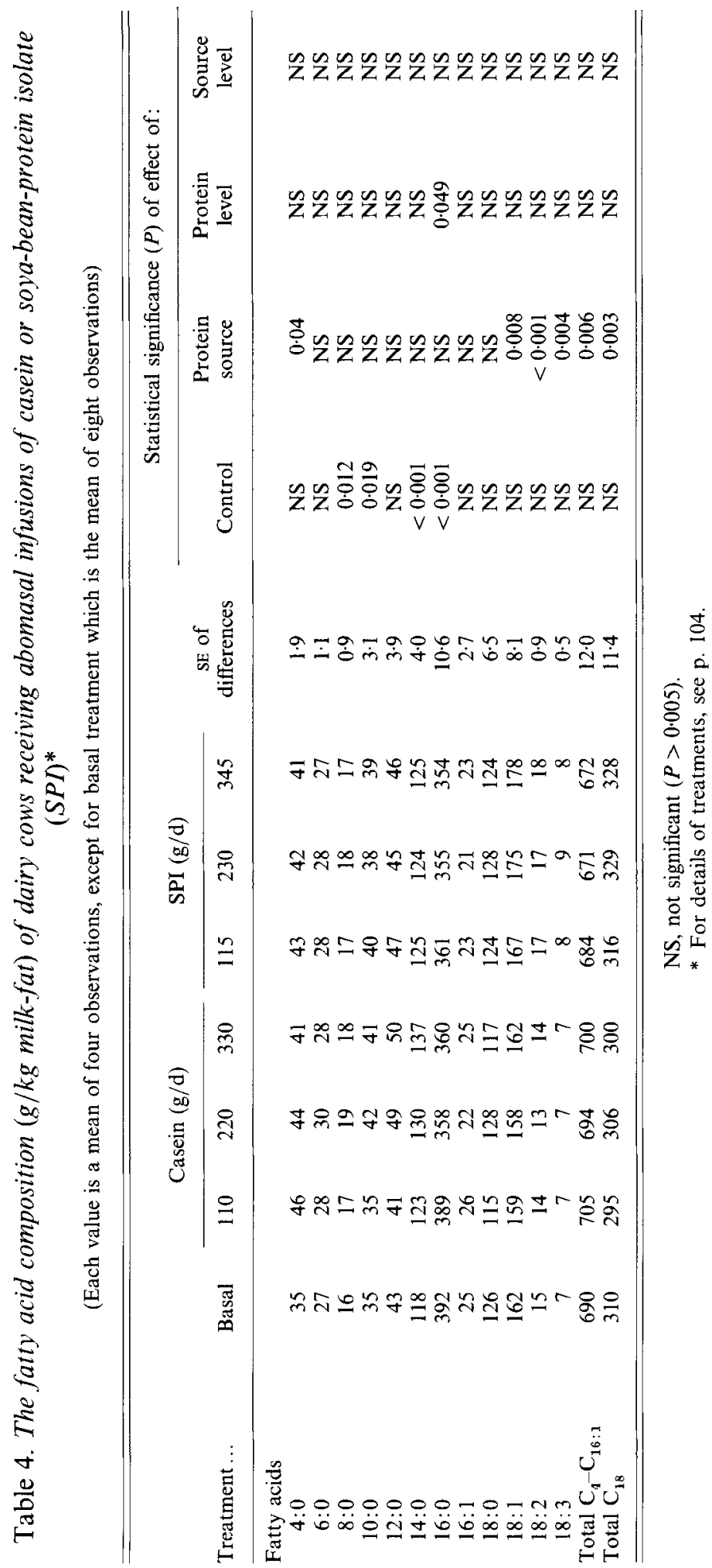


Table 5. The concentration of some metabolites in the blood plasma of dairy cows receiving abomasal infusions of casein or soya-bean-protein isolate (SPI)*

(Each value is a mean of four observations, except for basal treatment which is the mean of eight observations)

\begin{tabular}{lcccc}
\hline \hline Treatment & $\begin{array}{c}\text { Glucose } \\
(\mathrm{mg} / \mathrm{l})\end{array}$ & $\begin{array}{c}\beta \text {-Hydroxybutyrate } \\
(\mathrm{mg} / \mathrm{l})\end{array}$ & $\begin{array}{c}\text { Non-esterified } \\
\text { fatty acids } \\
(\mathrm{mmol} / \mathrm{l})\end{array}$ & $\begin{array}{c}\text { Urea } \\
(\mathrm{mg} / \mathrm{l})\end{array}$ \\
\hline Basal & 664 & 26 & $0 \cdot 08$ & 206 \\
Casein $(\mathrm{g} / \mathrm{d})$ & & 28 & & \\
110 & 671 & 30 & $0 \cdot 11$ & 204 \\
220 & 669 & 28 & $0 \cdot 11$ & 244 \\
330 & 657 & & $0 \cdot 12$ & 234 \\
SPI $(\mathrm{g} / \mathrm{d})$ & & 22 & & \\
115 & 710 & 21 & $0 \cdot 07$ & 215 \\
230 & 699 & $1 \cdot 7$ & $0 \cdot 07$ & 210 \\
345 & 674 & & $0 \cdot 07$ & 216 \\
SE of differences & $21 \cdot 6$ & $0 \cdot 01$ & $16 \cdot 0$ \\
Statistical significance $(P)$ of effect of: & NS & NS & NS & NS \\
Control & NS & $<0.001$ & $<0 \cdot 001$ & NS \\
Protein source & NS & NS & NS & NS \\
Protein level & NS & NS & NS & NS \\
Source level & NS & & \\
\hline \hline
\end{tabular}

NS, not significant $(P>0 \cdot 05)$.

* For details of treatments, see p. 104.

observed output of energy in milk was $128 \mathrm{MJ} / \mathrm{d}$, leaving an excess of $27 \mathrm{MJ} / \mathrm{d}$. Even allowing for the reported low $k_{l}$ for silage diets by assuming a value of 0.58 (Unsworth, 1990) still leaves an excess of $20 \mathrm{MJ} / \mathrm{d}$. Although measurements of live-weight changes are subject to error, on average the animals gained about $40 \mathrm{~kg}$ during the 9-week period of the experiment thus lending support to the energy calculations. Similarly, the supply of protein from the basal diet can be compared with the requirements for maintenance and the observed milk production (Agricultural Research Council, 1984). The supply of rumendegradable $\mathrm{N}$ (RDN) was $38.6 \mathrm{~g} / \mathrm{kg}$ OM digested in the rumen (DOMR), which is well in excess of the assumed microbial yield of $30 \mathrm{~g} \mathrm{~N} / \mathrm{kg}$ DOMR. The total supply of amino acid- $\mathrm{N}$ to the tissues was $34 \%$ in excess of that needed to meet the requirements of maintenance and milk production.

Hence, the nutritional and physiological status of the cows in the present experiment contrasted sharply with that of the cows used in previous experiments (Ørskov et al. 1977; Whitelaw et al. 1986) in which the animals were in early lactation and deliberately underfed.

The cows responded to casein infusion with marked increases in the yield of milk and milk constituents. The dose levels of casein in the current experiment covered a lower range than in the other two studies but, as can be seen from Fig. 1, the highest level of $330 \mathrm{~g} / \mathrm{d}$ produced increases in milk-protein yield of $160 \mathrm{~g} / \mathrm{d}$, substantially in excess of that reported by Whitelaw et al. (1986) and compatible with that observed by Ørskov et al. (1977). On the other hand, the present study and that of Whitelaw et al. (1986) are similar in the observed pattern of response of milk-fat output; in both studies, the yield of milk-fat reached a maximum with the second level of infusion and was actually decreased by the highest dose level, such that the increase in the energy output in milk reached a 'plateau' at between 10 and $12 \mathrm{MJ} / \mathrm{d}$. In contrast, in the experiment of Ørskov et al. (1977), in which the energy intake of the cows was severely restricted, the output of milk-fat increased 
ABOMASAL INFUSION OF PROTEINS IN DAIRY COWS

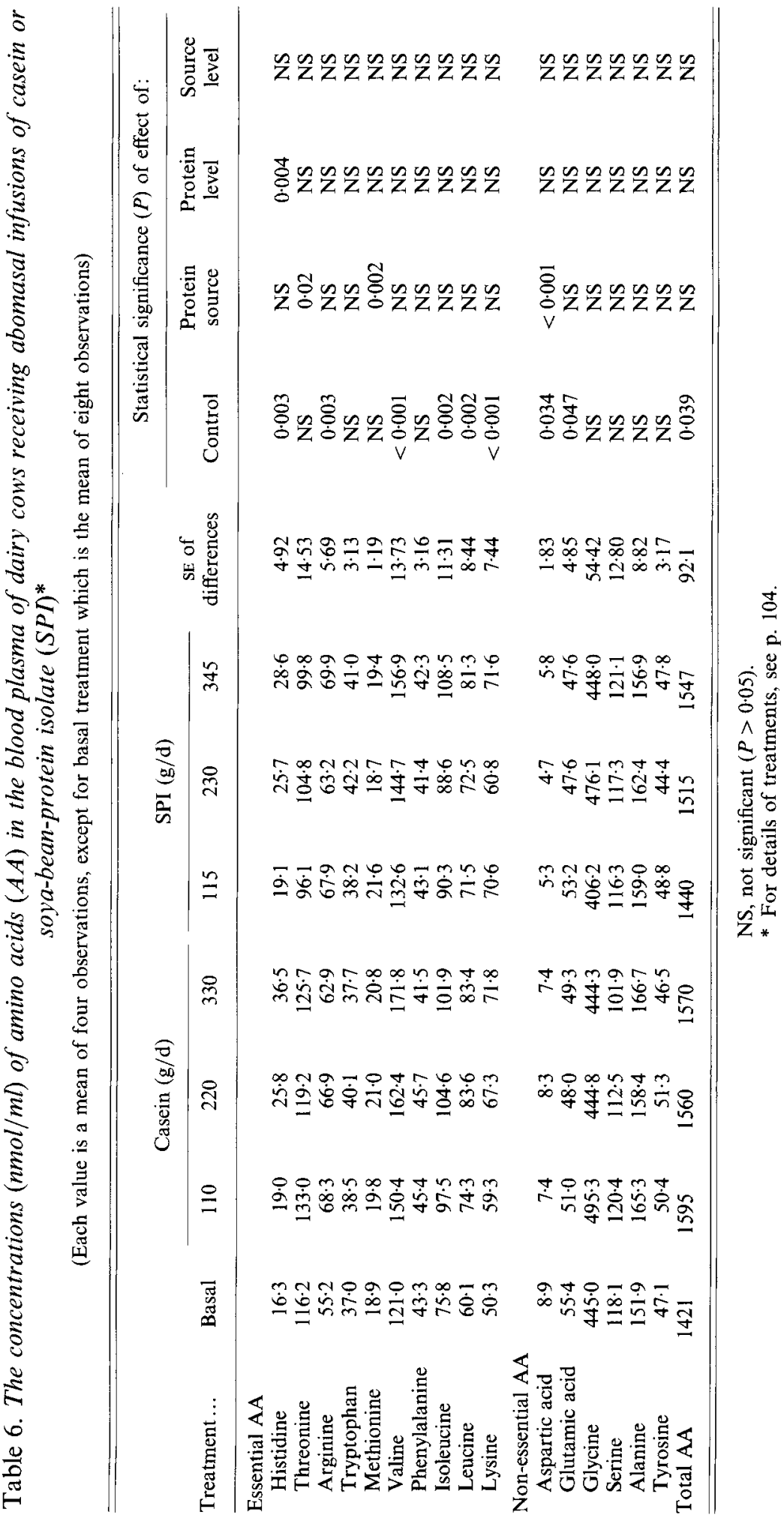




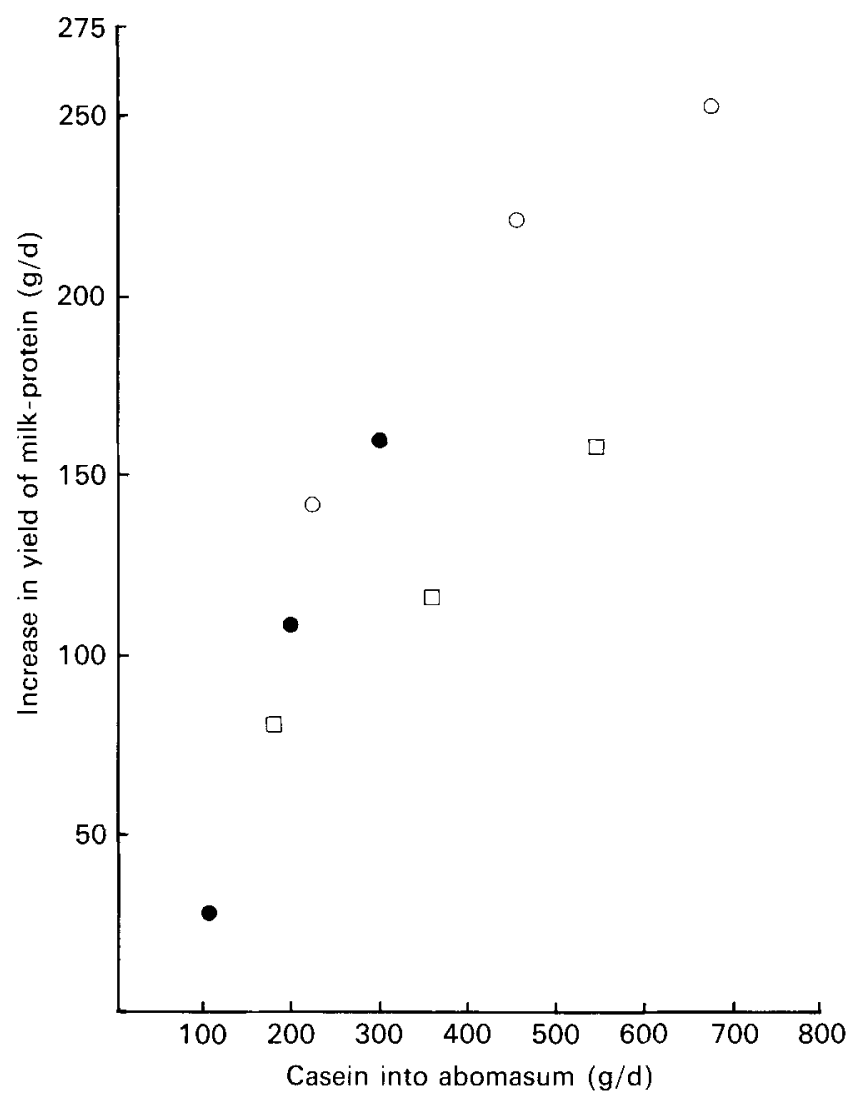

Fig. 1. The increase in the yield of protein in milk (g/d) relative to the amount of casein infused into the abomasum $(\mathrm{g} / \mathrm{d})$ in dairy cows. Values are from Orskov et al. (1977) $(\mathrm{O})$; Whitelaw et al. (1986) $(\square)$ and the present study (O).

progressively with each dose level of casein with the result that the increase in the output of energy in milk with the highest level of casein $(750 \mathrm{~g} / \mathrm{d})$ was much greater at about $24 \mathrm{MJ} / \mathrm{d}$.

All three studies have demonstrated that casein infused into the abomasum can produce increases in the output of energy in milk by amounts far greater than the energy supplied by the casein itself. However, whereas when the cows are underfed the extra energy is supplied by mobilized body stores, when the cows are consuming energy and protein in excess of requirement the extra energy comes either from a repartitioning of nutrient use between body tissues and milk synthesis or from an improved $k_{l}$. The biggest effect was seen with the $220 \mathrm{~g}$ casein/d level. Assuming a $k_{l}$ of 0.63 (Agricultural Research Council, 1980) for dietary $\mathrm{ME}$ and for the gross energy supplied in casein, it can be calculated that an extra $12 \mathrm{MJ} \mathrm{ME} / \mathrm{d}$ was channelled into milk synthesis, over and above that supplied by the casein itself. The repartitioning of this amount of $\mathrm{ME}$ is compatible with the calculation of energy balance made earlier. Alternatively it is possible that the increased energy output was derived from an increase in $k_{l}$ as suggested by Cowan et al. 1981. To account for the effect of casein in this way would require an increase in $k_{l}$ from 0.50 on the basal treatment to 0.58 with the casein infusion; both values are well within the range reported for silagebased diets (Unsworth, 1990). Although the measurements made in the present experiment do not allow these two mechanisms to be differentiated, calorimetric studies have failed to 
show any effect of protein supply on $k_{l}$ (Tyrrell \& Moe, 1980; Trigg et al. 1983; Tyrrell et al. 1983; Vermorel et al. 1983; Whitelaw et al. 1986). On balance, then, the effects of casein infusion in the present experiment are more likely to derive from effects on the partition of energy between body tissues and milk. If this interpretation is correct it has important implications for the study of nutrition-endocrine interactions. In cows underfed in early lactation the effects of casein infusion may be visualized as reinforcing the expected homeorrhetic drive in early lactation (Bauman \& Currie, 1980) by increasing the mobilization of body tissue to support milk secretion. However, later in lactation, as in the cows in the present experiment, the homeorrhetic drive would be expected to begin to encourage the partition of some of the absorbed nutrients into body tissues. These results suggest that, at this stage of lactation, the homeorrhetic mechanism is still sufficiently flexible to permit substantial modification of nutrient partition via manipulation of nutrient inputs.

Apart from the first level of infusion, for which increases in the outputs of fat and protein in milk were similar for both proteins, the overall effect on the yield of milk and milk constituents was much less for SPI than for casein. For the highest level of SPI the increases over the basal treatment were 13,12 and $8 \%$ for the yields of protein, fat and lactose respectively; as a consequence, the concentrations of protein and fat in the milk were increased.

As mentioned earlier, the supply of absorbed amino acids would be expected to be considerably in excess of requirements (Agricultural Research Council, 1984). If the supply of absorbed amino acids surplus to maintenance is calculated using the factors given by the Agricultural Research Council (1984), then the estimated efficiency of utilization of these amino acids for milk-protein synthesis was about 0.5 for the basal treatment. Despite this, at the first level of infusion both proteins produced an increase in the output of milkprotein, the transfer rate being $0 \cdot 4-0 \cdot 5$. Beyond the first level there was no further response of milk-protein yield to SPI infusion.

Compared with the amino acid composition of duodenal digesta in cows receiving a diet very similar to that used here (Chamberlain et al. 1986), SPI is richer only in histidine, arginine and phenylalanine, whereas casein contains higher proportions of histidine, methionine, valine, phenylalanine, leucine and lysine. However, again with diets similar to that used here, supplementing soya-bean-protein with rumen-protected forms of methionine and lysine has not improved production responses (see Chamberlain et al. 1989).

Attempting to explain differences between casein and SPI in terms of their ability to provide the amino acids required for the synthesis of milk-protein may not be the correct approach. In the circumstances of the present experiment the origin of the responses, to a large extent, may lie elsewhere. The marked difference between the protein sources in responses in the de novo synthesis of fatty acids in the mammary gland presumably reflects changes in the pattern of acetate utilization. A stimulation of acetate utilization for milkfat synthesis at the expense of adipose tissue synthesis would be consistent with the observation that abomasal infusion of casein depressed plasma insulin levels whereas infusion of SPI increased them (Choung \& Chamberlain, 1992). It is noteworthy also that in studies in simple-stomached animals casein and SPI have very different effects on lipid metabolism which have been linked to differences in their amino acid compositions (Sugano et al. 1982).

More detailed investigation of the effects of abomasally-infused protein sources on lipid metabolism in dairy cows might prove a more fruitful approach to understanding the underlying mechanisms. Such studies should gain impetus from the knowledge that the effects of casein are not only sizeable but, apparently, are not restricted to the early stages 
of lactation and, if they can be reproduced with other proteins or amino acids, can be expected to have wide-ranging implications for milk production systems.

The authors thank Mr M. K. Wait, Mrs E. Mitchell and Mrs I. Stewart for skilled technical assistance, Dr P. A. Martin for the surgical preparation of the animals and Mr J. R. Munro and his staff for care of the animals during the experiment. They are grateful to Dr D. Hirst, Scottish Agricultural Statistics Services, for statistical advice. This research was funded by the Scottish Office Agriculture and Fisheries Department.

\section{REFERENCES}

Agricultural Research Council (1980). The Nutrient Requirements of Ruminant Livestock. Farnham Royal: Commonwealth Agricultural Bureaux.

Agricultural Research Council (1984). The Nutrient Requirements of Ruminant Livestock, Suppl. no. 1. Farnham Royal: Commonwealth Agricultural Bureaux.

Bauman, D. E. \& Currie, W. B. (1980). Partitioning of nutrients during pregnancy and lactation: a review of mechanisms involving homeostasis and homeorhesis. Journal of Dairy Science 63, 1514-1529.

Chamberlain, D. G., Martin, P. A. \& Robertson, S. (1989). Optimizing compound feed use in dairy cows with high intakes of silage. In Recent Advances in Animal Nutrition-1989, pp. 175-193 [W. Haresign and D. J. A. Cole, editors]. London: Butterworths.

Chamberlain, D. G., Thomas, P. C. \& Quig, J. (1986). Utilization of silage nitrogen in sheep and cows: amino acid composition of duodenal digesta and rumen microbes. Grass and Forage Science 41, 31-38.

Choung, J. J. \& Chamberlain, D. G. (1992). Protein nutrition of dairy cows receiving grass silage diets. Effects on silage intake and milk production of postruminal supplements of casein or soya-protein isolate and the effects of intravenous infusions of a mixture of methionine, phenylalanine and tryptophan. Journal of the Science of Food and Agriculture 58, 307-315.

Clark, J. H. (1975). Lactational responses to postruminal administration of proteins and amino acids. Journal of Dairy Science 58, 1178-1197.

Cottyn, B. G. \& Boucque, G. N. (1968). Rapid method for the gas chromotographic determination of volatile fatty acids in rumen fluid. Journal of Agricultural and Food Chemistry 16, 105-107.

Cowan, R. J., Robinson, J. J., McHattie, I. \& Pennie, K. (1981). Effects of protein concentration in the diet on milk yield, change in body composition and the efficiency of utilization of body tissue for milk production in ewes. Animal Production 33, 111-120.

Dewar, W. A. \& McDonald, P. (1961). Determination of dry matter in silage by distillation with toluene. Journal of the Science of Food and Agriculture 12, 790-795.

Elsden, S. R. \& Gibson, Q. H. (1954). The estimation of lactic acid using ceric sulphate. Biochemical Journal 58, $154-158$.

Givens, D. I. (1986). New methods for predicting the nutritive value of silage. In Developments in Silage 1986, pp. 66-75 [B. A. Stark and J. M. Wilkinson, editors]. Marlow, Bucks: Chalcombe Publications.

Goering, H. K. \& Van Soest, P. J. (1970). Forage Fiber Analysis. USDA Agriculture Handbook no. 379, pp. 1-20. Beltsville, MD: US Department of Agriculture.

Huida, L. (1982). Gas chromatographic determination of water and ethanol in silage by internal standard method. Journal of the Agricultural Society of Finland 54, 137-143.

Keutmann, H. T. \& Potts, J. T. (1969). Improved recovery of methionine after acid hydrolysis using mercaptoethanol. Analytical Biochemistry 29, 175-185.

König, B. A., Oldham, J. D. \& Parker, D. S. (1984). The effect of abomasal infusion of casein on acetate, palmitate and glucose kinetics in cows during early lactation. British Journal of Nutrition 52, 319-328.

MacLeod, N. A., Corrigall, W., Stirton, R. A. \& Ørskov, E. R. (1982). Intragastric infusion of nutrients in cattle. British Journal of Nutrition 47, 547-552.

MacRae, J. C. \& Armstrong, D. G. (1968). Enzyme method for the determination of $\alpha$-linked glucose polymers in biological materials. Journal of the Science of Food and Agriculture 19, 578-581.

Ministry of Agriculture, Fisheries and Food (1981). The Analysis of Agricultural Materials. Technical Bulletin RB 427. London: H.M. Stationery Office.

Ørskov, E. R., Grubb, D. A. \& Kay, R. N. B. (1977). Effect of postruminal glucose or protein supplementation on milk yield and composition in Friesian cows in early lactation and negative energy balance. British Journal of Nutrition 38, 397-405.

Payne, R. W., Lane, P. W., Ainsley, H. E., Bricknell, K. E., Digby, P. G. N., Harding, S. A., Leech, P. K., Simpson, H. R., Todd, A. P., Verrier, P. J. \& White, R. P. (1987). Genstat 5 Reference Manual. Oxford: Clarendon Press.

Rulquin, H. (1982). Effets sur la digestion et le métabolisme des vaches laitières d'infusions d'acides gras volatils dans le rumen et de caséinate dans le duodenum. 1. Production et digestion (Effects of the infusion of volatile 
fatty acids into the rumen and caseinate into the duodenum on digestion and metabolism in dairy cows 1. Production and digestion). Reproduction, Nutrition Developpement 22, 905-921.

Somogyi, M. (1945). A new reagent for the determination of sugars. Journal of Biological Chemistry 160, 61-68. Sugano, M., Ishiwaki, N., Nagata, Y.\& Imaizumi, K. (1982). Effects of arginine and lysine addition to casein and soya-bean protein on serum lipids, apolipoproteins, insulin and glucagon in rats. British Journal of Nutrition $\mathbf{4 8 ,}$ 211-221.

Thomas, P. C. \& Kelly, M. E. (1976). The effect of frequency of feeding on milk secretion in the Ayrshire cow. Journal of Dairy Research 43, 1-7.

Trigg, T. E., Parr, C. R., Day, A. M. \& Parsons, B. W. (1983). Effects on milk production and energy metabolism of abomasal infusions of protein to lactating, pasture-fed dairy cows. In Energy Metabolism of Farm Animals. European Association of Animal Production Publications no. 29, pp, 42-45 [A. Akern and F. Sundstøl, editors]. Ski, Norway: Informasjonsteknikk A/S.

Tyrrell, H. F., Haaland, G. L., Moe, P. W. \& Brown, A. C. G. (1983). Effect of level and solubility of dietary protein on the energy value of rations fed to lactating dairy cows. In Energy Metabolism of Farm Animals. European Association of Animal Production Publication no. 29, pp. 14-17 [A. Akern and F. Sundstøl, editors]. Ski, Norway: Informasjonsteknikk A/S.

Tyrrell, H. F. \& Moe, P. W. (1980). Effect of protein level and buffering capacity on energy value of feeds for lactating dairy cows. In Energy Metabolism, pp. 311-313 [L. E. Mount, editor]. London: Butterworths.

Umagat, H., Kucera, P. \& Wem, L. H. (1982). Total amino acid analysis using pre-column fluorescence derivatization. Journal of Chromatography 239, 463-474.

Unsworth, E. F. (1990). The efficiency of utilization of metabolizable energy for lactation from grass silage-based diets. In Proceedings of the Ninth Silage Conference, pp. 36-37. Newcastle-upon-Tyne: University of NewcastleUpon-Tyne.

Vermorel, M., Remond, B., Vernet, J. \& Liamadis, D. (1983). Utilization of body reserves by high-producing cows in early lactation: effects of crude protein and amino acid supply. In Energy Metabolism of Farm Animals. European Association of Animal Production Publication no. 29, pp. 18-21 [A. Akern and F. Sundstøl, editors]. Ski, Norway: Informasjonsteknikk A/S.

Waite, R., White, J. C. D. \& Robertson, A. (1956). Variations in the chemical composition of milk with particular reference to the solids-not-fat. 1 . The effect of stage of lactation, season of year and age of cow. Journal of Dairy Research 23, 65-81.

Whitelaw, F. G., Milne, J. S., Ørskov, E. R. \& Smith, J. S. (1986). The nitrogen and energy metabolism of lactating cows given abomasal infusion of casein. British Journal of Nutrition 55, 537-556. 